\title{
Første- og andrespråklige sykepleiere har ulik journalføring
}

\section{Forfattere}

\author{
Lasse Morten Johannesen \\ Førstelektor \\ Institutt for lingvistiske og nordiske studier, Universitetet i Oslo
}

Ragnhild Hellesø

Professor

Avdeling for sykepleievitenskap, Institutt for helse og samfunn, Universitetet i Oslo

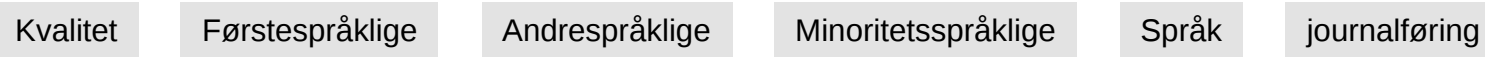

Språklig repertoar

Sykepleien Forskning 2019 14(76342)(e-76342)

DOI: https://doi.org/10.4220/Sykepleienf.2019.76342

\section{Sammendrag}

Bakgrunn: Det har vært økende arbeidsvandring av sykepleiere over landegrensene de siste tiårene. Det er et lederansvar å sikre at ansatte har nødvendige språklige ferdigheter. Vi har ikke identifisert studier som sammenlikner pasientjournaler skrevet av førstespråklige sykepleiere og andrespråklige sykepleiere.

Hensikt: Hensikten med studien var å utforske forskjeller og likheter i omfang og språklig presisjon mellom første- og andrespråklige sykepleieres vaktskifterapporter. 
Metode: Vi brukte et utforskende design for å vurdere 113 vaktskifterapporter, der 57 var skrevet av 17 sykepleiere med norsk som førstespråk, og 56 var skrevet av 17 sykepleiere med et annet førstespråk.

Resultat: De førstespråklige sykepleierne journalførte hovedsakelig mer enn andrespråklige. Andrespråklige journalførte imidlertid nesten like mye når det gjaldt tallstørrelser, og mer når det gjaldt informasjon om familie og pårørende. Funnene avdekket at de andrespråklige hadde et mindre repertoar og lavere språklig presisjon.

Konklusjon: Første- og andrespråklige sykepleiere journalfører nesten like mye tallrelatert informasjon, men i det språklige repertoaret og registeret er det klare forskjeller mellom gruppene. De førstespråklige sykepleierne bruker et større og mer nyansert repertoar enn andrespråklige sykepleiere. Studien gir ikke grunnlag for å trekke slutninger om at førstespråklige sykepleiere har feilfri journalføring, men den kan bidra til å iverksette tiltak som kan lette journalføringen for en sykepleiergruppe som er økende, og som Norge har bruk for.

\section{Rettelse 25.04.2019}

Vi gjør oppmerksomme på at vi har endret en setning under «Setting og utvalg» som kunne misforstås. Følgende setning ble endret:

«De kunne ikke ha et skandinavisk morsmål, være fast ansatte eller være uten videreutdanning.»

Den nye setningen lyder som følger:

«De skulle være fast ansatte uten videreutdanning, og de kunne ikke ha et skandinavisk morsmål.»

I denne artikkelen setter vi søkelyset på journalføring utført av sykepleiere med norsk som førstespråk og sykepleiere med norsk som andrespråk. Sykepleiere må bruke et klart og tydelig språk i journalføringen for å unngå misforståelser og feil. Sykepleiere med utdanning fra andre land enn Norge og andrespråklige sykepleierstudenter kan ha språkutfordringer både under utdanningen og i yrkeslivet $(1,2)$. 
Studenter som tar utdanning i et land der de må bruke andrespråket i utdanningen, opplever ofte at overgangen fra videregående skole til for eksempel et sykepleiestudium er språklig krevende (1). Andrespråklige sykepleiere kan ha opplevd at de har utfordringer med å samhandle med pasienter og medarbeidere, og at de kan ha ulik forståelse av rollen som sykepleier (2).

\section{Studier av journalføring}

Generelt viser studier der det ikke skilles mellom første- og andrespråklige sykepleiere, at kvaliteten på journalføringen er av varierende grad (3-5), og at sykepleierne synes det er utfordrende å formulere sykepleieplaner (6). Journalkvaliteten kan bli svekket på grunn av et fragmentert språk (7), og journalene kan være ufullstendige med blant annet fraværende informasjon om effekten av sykepleietiltak (8).

En studie fra et tysk universitetssykehus (9) påviste til dels store mangler i pasientjournalene. De avdekket manglende samsvar mellom det som ble sagt under muntlig rapport, og det som var dokumentert i journalen, og at det var feil i viktig informasjon, eller at den manglet helt.

\section{Fordeler og ulemper for andrespråklige}

Det kan være språklige, faglige og kulturelt relaterte utfordringer for internasjonale sykepleiere og for andrespråklige sykepleierstudenter som tar utdanning i et annet land. Kanadiske studier viser at internasjonalt utdannede sykepleiere møter utfordringer med å takle engelsk som et akademisk språk når de tar etterutdanning, og når de møter uventede formelle krav (10).

Ulike faktorer kan sammen eller alene ha en positiv innvirkning på sykepleieres integrasjon og yrkesutøvelse. Blant annet trekkes økonomiske ressurser, generelle språkferdigheter og yrkesrelaterte språkferdigheter frem (11). 
En australsk studie (12) viser at målbevisst økt interaksjon med erfarne sykepleiere og pasienter bidrar til å forbedre andrespråklige sykepleieres ferdigheter i kommunikasjon og samhandling med pasienter og andre sykepleiere. Studien fremhever at det har betydning for språklig tilpasning hvordan sykepleieren ser på seg selv, og hvor forberedt han eller hun er før vedkommende begynner å arbeide i et annet land.

Deres måte å kommunisere på påvirker forventningene pasienter og annet helsepersonell har til den utenlandske sykepleieren.

Publikasjoner som påviser problemer knyttet til kommunikasjon med fremmedspråklige sykepleiere, bruker begrepet «språk» tilsynelatende bare i forbindelse med muntlig kommunikasjon $(2,13)$. Skriftlig dokumentasjon tas ikke opp, selv om den har en juridisk verdi som mangler ved muntlig kommunikasjon (14).

\section{Hensikten med studien}

I vår artikkel fokuserer vi på ferdigutdannede sykepleiere som har lagt bak seg fagutdanningen, og som oppfyller språkkravene. Vi har ikke funnet studier som har undersøkt språklige likheter og forskjeller mellom førstespråklige og andrespråklige sykepleieres journalføring, verken i Norge eller internasjonalt.

\section{三 «Det er nå vel 10 prosent av over hundre tusen sykepleiere, jordmødre og helsesykepleiere i Norge som ikke kommer fra Norge opprinnelig.»}

Fravær av slike studer er overraskende når det i enkelte land er en relativt stor andel av sykepleiere som ikke har landets offisielle språk som sitt morsmål. Det er nå vel 10 prosent av over hundre tusen sykepleiere, jordmødre og helsesykepleiere i Norge som ikke kommer fra Norge opprinnelig (15). 
Tilstrekkelig, relevant, presist og forståelig språkrepertoar, der pasientens egne synspunkter inkluderes, er nødvendig for å sikre kvalitet og kontinuitet (16). Hensikten med pilotstudien vår var å utforske forskjeller og likheter i omfang og språklig presisjon mellom første- og andrespråklige sykepleieres vaktskifterapporter.

\section{Metode}

Vi brukte en utforskende tilnærming for å undersøke sykepleiernes språklige ferdigheter. Vi identifiserte deres språklige register og grammatikalske uttrykk.

\section{Setting og utvalg}

Vaktskifterapporter skal bidra til å sikre kontinuitet og samhandling rundt pasienten $(4,14)$.

Avdelingssykepleiere ved fire avdelinger samlet inn skriftlige, anonymiserte rapporter fra dagvakter på et større sykehus på Østlandet. Rapporter fra dagvakter er vanligvis mer omfattende enn rapporter fra nattevakter og kveldsvakter.

I sykehusets elektroniske dokumentasjonssystem benevnes vaktskifterapporter som «Notat/evaluering», heretter kalt rapporter. Inklusjonskriteriene var at sykepleierne skulle ha norsk som førstespråk eller ha norsk som andrespråk. De skulle være fast ansatte uten videreutdanning, og de kunne ikke ha et skandinavisk morsmål.

Lederne samlet også inn informasjon om hvor lenge de hadde vært ansatt som sykepleiere i Norge, og hvor de hadde tatt sin avsluttende sykepleiereksamen.

\section{Datainnsamling}


En i sykehusledelsen kontaktet fem klinikkledere og ba om tillatelse til å gjennomføre studien. Fire samtykket i å delta med hver sin avdeling og sørget for en kontaktperson for den enkelte avdelingen.

Kontaktpersonene mottok ytterligere skriftlig og muntlig informasjon om prosjektets hensikt og fremgangsmåte fra førsteforfatteren.

Kontaktpersonene innhentet skriftlig samtykke fra sykepleierne til at rapporter de hadde skrevet, kunne samles inn og brukes i prosjektet. Før de samtykket, hadde de fått skriftlig informasjon om prosjektets hensikt, og om hvordan resultatene skulle brukes. Avdelingssykepleieren for hver enkelt avdeling anonymiserte personer og pasientidentifiserende informasjon.

Vi samlet inn rapportene fra avdelingene mellom juni 2015 og januar 2016. Det var et mål at ingen rapporter skulle være fra perioder der det gjerne forekommer flere vikarer eller dobbeltvakter, som jul, påske og sommerferie. Vi valgte samme vakt og utelot bestemte perioder for å unngå skjevheter mellom de to sykepleiergruppene.

I alt samlet vi inn 129 rapporter skrevet av 20 førstespråklige og 20 andrespråklige sykepleiere. Materialet vi fikk fra avdelingssykepleierne, viste seg også å inneholde rapporter fra kvelds- og nattevakter. Disse rapportene ble tatt ut av materialet, som til slutt besto av rapporter skrevet av 17 første- og 17 andrespråklige sykepleiere, representert med henholdsvis 57 og 56 rapporter.

Ti av de andrespråklige hadde sykepleierutdanning fra Norge, mens de øvrige sju var utdannet i utlandet. Flertallet av de førstespråklige hadde arbeidet fra ett til tre år som sykepleiere. Arbeidserfaringen for de andrespråklige var i gjennomsnitt lengre. Flertallet hadde arbeidet i fast stilling fra to til femten år. 
Av hensyn til anonymisering presenterer vi ikke resultatene på avdelingsnivå og utdanningssted, det vil si hvorvidt utdanningsstedet er innenfor eller utenfor Norge.

\section{Analyse}

Vi gjorde først en analyse for å identifisere kategorier på tvers av tolv funksjonsområder som det var forventet at sykepleierne skulle bruke i rapportene:

- kommunikasjon og sanser

- kunnskap, utvikling eller psykiske helseutfordringer

- åndedrett og sirkulasjon

- ernæring, væske- og elektrolyttbalanse

- eliminasjon

- hud, vev og sår

- aktivitets- og funksjonsstatus

- smerte, søvn, hvile og velvære

- seksualitet og reproduksjon

- sosiale behov

- åndelig, kulturelt behov og livsstilsutfordringer

- annet, legedelegerte aktiviteter og observasjoner

I denne fasen organiserte vi først materialet ut fra myndighetenes forventninger til journalføring (14). Deretter gjennomførte vi en tekstkondensering, der vi støttet oss til en grounded theory-tilnærming (17). 
Det resulterte i følgende seks tverrgående kategorier:

1) sykepleierens vurderinger og sykepleiediagnoser,

2) sykepleierens tiltak og handlinger, 3)

kommunikasjon mellom pasienten og sykepleieren, 4)

samarbeid og kommunikasjon med annet

helsepersonell, 5) notater som omfatter familie,

pårørende og venner, og 6) tallrelaterte

informasjonsenheter som blodtrykk, feber, smertegrad og klokkeslett.

For å gjøre det mulig å sammenlikne de to sykepleiergruppene oppsummerte vi hvor mange ganger hver sykepleier dokumenterte under hver kategori, og regnet deretter ut gjennomsnittlig antall informasjonsenheter per notat. For eksempel er det hos førstespråklige sykepleiere dokumentert 108 tilfeller av «kommunikasjon mellom pasienten og sykepleieren» i de 57 rapportene. Vi angir disse tilfellene som et gjennomsnitt på 1,9 per rapport. Den gruppen sykepleiere som dokumenterte mest innen hver kategori, ble satt til 100 prosent, noe som gjør det mulig å vise den relative forskjellen mellom andre- og førstespråklige sykepleiere.

\section{Dybdeanalyse av hud, vev og sår}

Sykehuspasienter er utsatt for infeksjoner (18) og sår (19). Det kreves både fag- og språkkompetanse for å kunne uttrykke presist hvordan et sår ser ut langs en tidslinje, altså hvordan såret var og er, hvilke tiltak som ble iverksatt på foregående vakt(er), samt å peke på eventuell nødvendig oppfølging på kommende vakt(er).

Vi gjorde derfor en dybdeanalyse av funksjonsområdet «hud, vev og sår» for å undersøke språklig presisjonsnivå gjennom nyanser. Vi undersøkte uttrykk for variasjon i ulike vurderinger, tiltak og handlinger, beskrivelser av tid og endringer samt kommunikasjon og samarbeid. 
Vi valgte å sammenlikne journalføringen til de to sykepleiergruppene basert på 1) register over ordforråd av blod, 2) register over symptomer angitt med farger og lyst eller mørkt, 3) register over ulike dokumenterte tiltak eller handlinger, 4) register over ulike dokumenterte bandasjetyper, 5) uttrykk for tilstand og endringer over tid, og 6) samarbeid og kommunikasjon med annet helsepersonell og pasienten.

Kategori 6 ble inkludert siden samarbeid og kommunikasjon skal styrke kvaliteten på pasientoppfølgingen, og de innbefatter også enveiskommunikasjon i form av direkte henvendelser til påtroppende skift.

\section{Etikk}

Prosjektet var et kvalitetssikringsprosjekt og ble vurdert og godkjent av sykehusets personvernombud for forskning. Sykepleierne samtykket til at vi kunne bruke rapportene de hadde skrevet, i analysen. De hadde fjernet all pasientidentifiserende informasjon fra rapportene vi mottok.

Vi informerte sykepleierne om at ingen enkeltavdelinger skulle kunne identifiseres i publikasjoner. Det samme gjaldt for enkeltsykepleiere og ulike grupper av sykepleiere etter nasjonal eller kulturell bakgrunn.

\section{Resultater}

Et hovedfunn er at førstespråklige sykepleiere dokumenterer mer enn andrespråklige for disse kategoriene: «sykepleierens vurdering og sykepleiediagnoser», «sykepleierens tiltak eller handlinger», «kommunikasjon mellom pasienten og sykepleieren» og «samhandling med annet helsepersonell». 
For kategorien «familie, pårørende og venner»

dokumenterte de andrespråklige mer enn

førstespråklige. I kategorien «tallrelaterte

informasjonsenheter» var det en liten overvekt av

dokumentasjon hos førstespråklige. I tabell 1 viser vi

forskjellene i omfang av informasjon med eksempler

på hvordan de to sykepleiergruppene dokumenterer.

Tabell 1. Første- og andrespråklige sykepleieres omfang av informasjon for hovedkategoriene.

\begin{tabular}{|c|c|c|c|}
\hline Hovedkategorier & Førstespråklige (F) & Andrespråklige (A) & $\begin{array}{l}\text { Eksempler fra dokumentasjon med } \\
\text { kommentarer }\end{array}$ \\
\hline $\begin{array}{l}\text { Sykepleiers vurderinger } \\
\text { og diagnoser }\end{array}$ & 4,4 & $\begin{array}{l}3,2 \\
(73 \% \text { av F) }\end{array}$ & $\begin{array}{l}\text { «Pas. er trøtt, vært sovende hele tiden } \\
\text { men lett vekkbar.» (A) } \\
\text { «Har mye smerter i rygg ved mobilisering } \\
\text { og gange, rynker ansiktet og ynker seg.» }(\mathrm{F})\end{array}$ \\
\hline $\begin{array}{l}\text { Sykepleiers tiltak } \\
\text { og handlinger }\end{array}$ & 2,2 & $\begin{array}{l}0,9 \\
(41 \% \text { av F) }\end{array}$ & $\begin{array}{l}\text { "Sliten, trøtt, spurt om sove medisinen, } \\
\text { fått sove imovane } 5 \mathrm{mg} \mathrm{kl} .20-15 »(\mathrm{~A}) \\
\text { «Etter at pas ble mer hoven på sidene av } \\
\text { magen, har u.t. tatt ned tempoet til } 280 \mathrm{ml} / \mathrm{t} . \text {. (F) }\end{array}$ \\
\hline $\begin{array}{l}\text { Kommunikasjon mellom } \\
\text { pasient og sykepleier }\end{array}$ & 1,9 & $\begin{array}{l}1,1 \\
(58 \% \text { av F) }\end{array}$ & $\begin{array}{l}\text { «Forteller han føler at det er på } \\
\text { bedringens vei.» (A) } \\
\text { «Orienterer pasienten, svarer adekvat på } \\
\text { dette.» (F) }\end{array}$ \\
\hline $\begin{array}{l}\text { Samarbeid med annet } \\
\text { helsepersonell }\end{array}$ & 0,8 & $\begin{array}{l}0,5 \\
(63 \% \text { av F) }\end{array}$ & $\begin{array}{l}\text { «Kontaktet Hjemmtjenste og meldt pas } \\
\text { muntlig.» (A) } \\
\text { «Ringt til anestesi, har ikke fått noe svar.» (F) }\end{array}$ \\
\hline $\begin{array}{l}\text { Familie, pårørende } \\
\text { og venner }\end{array}$ & $\begin{array}{l}0,5 \\
(71 \% \text { av } F)\end{array}$ & 0,7 & $\begin{array}{l}\text { «Pårørende } \emptyset \text { nsket å få henne på bes } \emptyset \mathrm{k} \text { hjem } \\
\text { i noen timer i morgen.» (A) } \\
\text { «[...] har vært oppe og gått i korridoren med } \\
\text { kona.» (F) }\end{array}$ \\
\hline $\begin{array}{l}\text { Tallrelaterte informasjons- } \\
\text { enheter }\end{array}$ & 4,9 & $\begin{array}{l}4,7 \\
(96 \% \text { av F) }\end{array}$ & $\begin{array}{l}\text { "[...] ustabil pulsen, som ble målt x 2, kl. 13-00 } \\
\text { pulsen 168, kontroll måling kl. } 14-00 \text { pulsen } \\
84 . »(A) \\
\text { «Eliminasjon: KAD tømt for } 1500 \mathrm{ml} \text {, lys og klar } \\
\text { diurese kl. 19:00.» (F) } \\
\text { Kommentar: I eksemplene her har vi regnet } \\
\text { fem tallrelaterte informasjonsenheter for A, } \\
\text { og to for F. }\end{array}$ \\
\hline
\end{tabular}

Figur 1 viser den relative forskjellen i omfanget av hovedkategoriene mellom de to sykepleiergruppenes journalføring. 


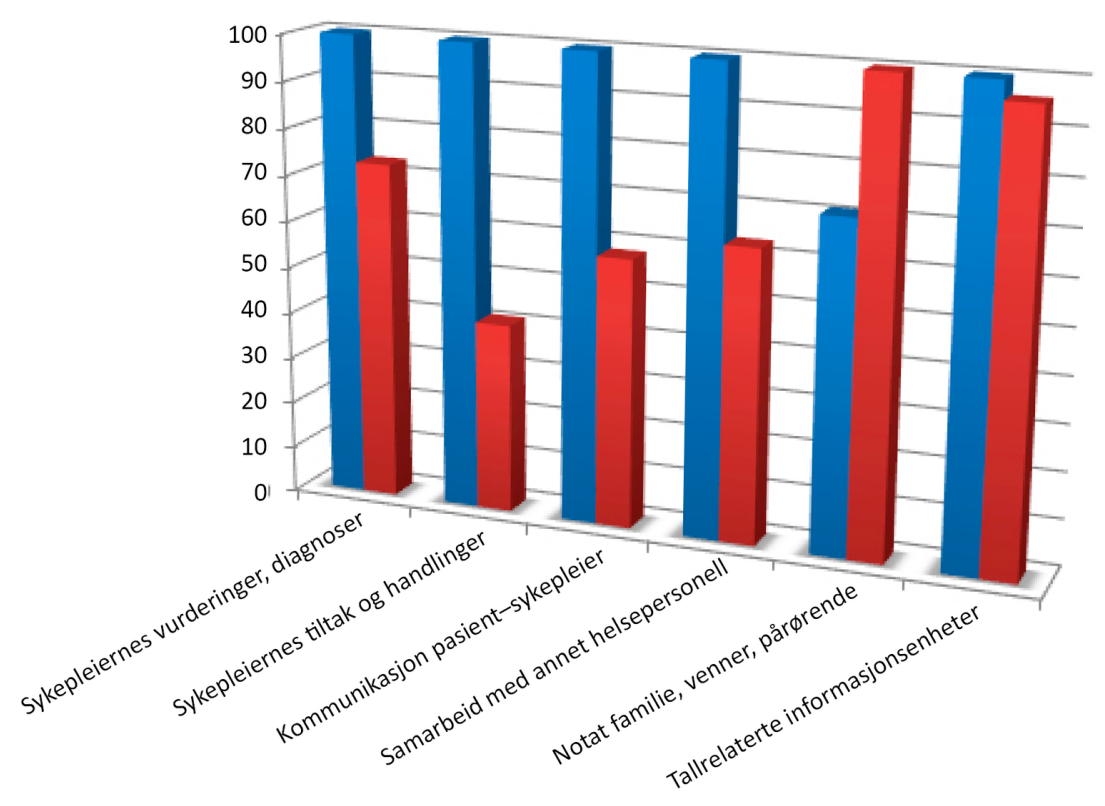

Relative forskjeller i dokumentasjonsomfang for førstespråklige (blå søyle) og andrespråklige sykepleiere ( $r \varnothing \mathrm{d} s \varnothing \mathrm{yle}$ ) for hovedkategoriene.

\section{Andrespråklige har lavere språklig presisjon}

I detaljanalysen av språklig presisjon fant vi at de andrespråklige hadde informasjon i 37 av de 56 rapportene (66 prosent), mens de førstespråklige hadde dokumentert i 51 av de 57 (89 prosent). De andrespråklige har lavere språklig presisjon med færre nyanser. Det kommer blant annet frem når de dokumenterer observasjoner av sårstell og bandasjeskift. Førstespråklige bruker et register med ti ulike ord relatert til observasjon av bandasje, mens hos andrespråklige identifiserte vi kun én beskrivelse.

\section{三 «De andrespråklige har lavere språklig presisjon med færre nyanser.»}

I tabell 2 viser vi forskjeller i nyanser og presiseringer i dokumentasjonen. Også for nyanser i symptombeskrivelser med farger er det forskjell mellom de to gruppene - der de førstespråklige bruker dobbelt så mange beskrivelser. Når det gjelder register over ulike tiltak og handlinger, er det også dobbelt så mange hos gruppen av førstespråklige - i alt tolv ulike mot seks hos de andrespråklige. 
Tabell 2. Eksempel på første- og andrespråklige sykepleieres språklige presisjon og nyanseringer

\begin{tabular}{|c|c|c|c|}
\hline Kategorier & Førstespråklige (F) & $\begin{array}{l}\text { Andrespråklige } \\
\text { (A) }\end{array}$ & Kommentarer/oppsummeringer \\
\hline $\begin{array}{l}\text { Register for ordforråd knyttet } \\
\text { til blod }\end{array}$ & $\begin{array}{l}\text { blod } \\
\text { blodig } \\
\text { blø } \\
\text { sive } \\
\text { blødning } \\
\text { blodvann } \\
\text { hematom } \\
\text { skygge } \\
\text { liten skygge } \\
\text { gammel rose }\end{array}$ & litt skygget & $\begin{array}{l}\text { Siste tre beskrivelser hos F dreier seg om } \\
\text { observasjoner i bandasje. }\end{array}$ \\
\hline $\begin{array}{l}\text { Register for symptom- } \\
\text { beskrivelse - farger/nyanser } \\
\text { for tilstand hud/vev }\end{array}$ & $\begin{array}{l}\text { rød } \\
\text { lett rød } \\
\text { veldig blålig } \\
\text { litt blå } \\
\text { gulaktig } \\
\text { mørk }\end{array}$ & $\begin{array}{l}\text { rød } \\
\text { litt rød } \\
\text { blek }\end{array}$ & \\
\hline $\begin{array}{l}\text { Register for ulike tiltak, } \\
\text { handlinger }\end{array}$ & $\begin{array}{l}\text { fjerne } \\
\text { skifte } \\
\text { bytte } \\
\text { seponere } \\
\text { avlaste } \\
\text { forsterke } \\
\text { legge på (bandasje) } \\
\text { legge inn (kanyle) } \\
\text { dekke } \\
\text { skylle } \\
\text { legge til rette } \\
\text { beholde }\end{array}$ & $\begin{array}{l}\text { fjerne } \\
\text { skifte } \\
\text { bytte } \\
\text { seponere } \\
\text { avlaste } \\
\text { smøre }\end{array}$ & $\begin{array}{l}\text { De fem første tiltakene hos F og A er like og } \\
\text { relativt generelle. } \\
\text { Deretter følger kun ett mer spesifikt tiltak hos A, } \\
\text { «smøre». Hos F følger sju mer spesifikke tiltak. } \\
\text { "Beholde» er dokumentert «ikke-handling», } \\
\text { dvs. å ikke skifte. }\end{array}$ \\
\hline $\begin{array}{l}\text { Register for ulike typer } \\
\text { bandasjer }\end{array}$ & $\begin{array}{l}\text { Allevyn } \\
\text { Aquacel } \\
\text { Duoderm } \\
\text { Jelonet } \\
\text { Mepore } \\
\text { Opsite } \\
\text { operasjonsbandasje } \\
\text { kompresjons- } \\
\text { bandasje }\end{array}$ & $\begin{array}{l}\text { Aquacel } \\
\text { Sårbandasje }\end{array}$ & $\begin{array}{l}\text { F spesifiserer typen bandasje i } 13 \text { av } 28 \text { notater } \\
\text { (46\%). A spesifiserer i } 2 \text { av } 14 \text { (14\%). }\end{array}$ \\
\hline $\begin{array}{l}\text { Notater som speiler dynam- } \\
\text { iske perspektiver som tid og } \\
\text { endring for hud, vev og sår } \\
\text { - tilstand før/under og/eller } \\
\text { etter aktuelt skift }\end{array}$ & $\begin{array}{l}\text { «Bandasjen ble } \\
\text { skiftet helt inn i går. } \\
\text { I dag er bandasjen } \\
\text { blodig og nesten } \\
\text { gjennomtrukket } \\
\text { ved ett område } \\
\text { der såret siver. } \\
\text { Observer videre for } \\
\text { å evt. skifte helt inn } \\
\text { i kveld.» }\end{array}$ & $\begin{array}{l}\text { «Bandasje på } \\
\text { ryggen er litt } \\
\text { skygget, men } \\
\text { er uendret } \\
\text { fra i går.» }\end{array}$ & 18 notater ( $35 \%)$ hos $\mathrm{F}$ og $2(5 \%)$ hos $\mathrm{A}$. \\
\hline $\begin{array}{l}\text { Samarbeid og kommunikasjon } \\
\text { med annet helsepersonell og } \\
\text { pasienter }\end{array}$ & $\begin{array}{l}\text { «Fikk beskjed fra } \\
\text { sykepleier på inten- } \\
\text { siven at det er en } \\
\text { begynnende [...].» }\end{array}$ & «obs ve. hæl» & $12(24 \%)$ notater hos $\mathrm{F}$ og $2(5 \%)$ hos $\mathrm{A}$. \\
\hline
\end{tabular}

\section{Førstespråklige dokumenterer mer om samarbeid}


Bandasjetype gir ekstra informasjon om såret og behandlingen som er gitt. De andrespråklige spesifiserer i 2 av 14 notater som inkluderer bandasje, mot 13 av 28 notater hos førstespråklige. De andrespråkliges notater gjenspeiler i svært liten grad endrings- og utviklingsaspektet, som er kritisk for området hud, vev og sår, altså for eksempel hvordan huden eller såret var under forrige vakt, og hva en eventuell endring frem til aktuell vakt består i.

Førstespråklige har langt mer dokumentasjon på samarbeid og kommunikasjon med annet helsepersonell og med pasientene. Hos de førstespråklige identifiserte vi tolv notater med dokumentasjon på ulike former for kommunikasjon og samarbeid. De andrespråklige hadde to notater i denne kategorien, og begge var direkte oppfordringer til kommende vakter og handlet ikke om kommunikasjon med pasienter.

I figur 2 viser vi grafisk forskjellen i registeret over ulike beskrivelser og handlinger hos de to sykepleiergruppene.

Figur 2. Forskjeller i språkrepertoar

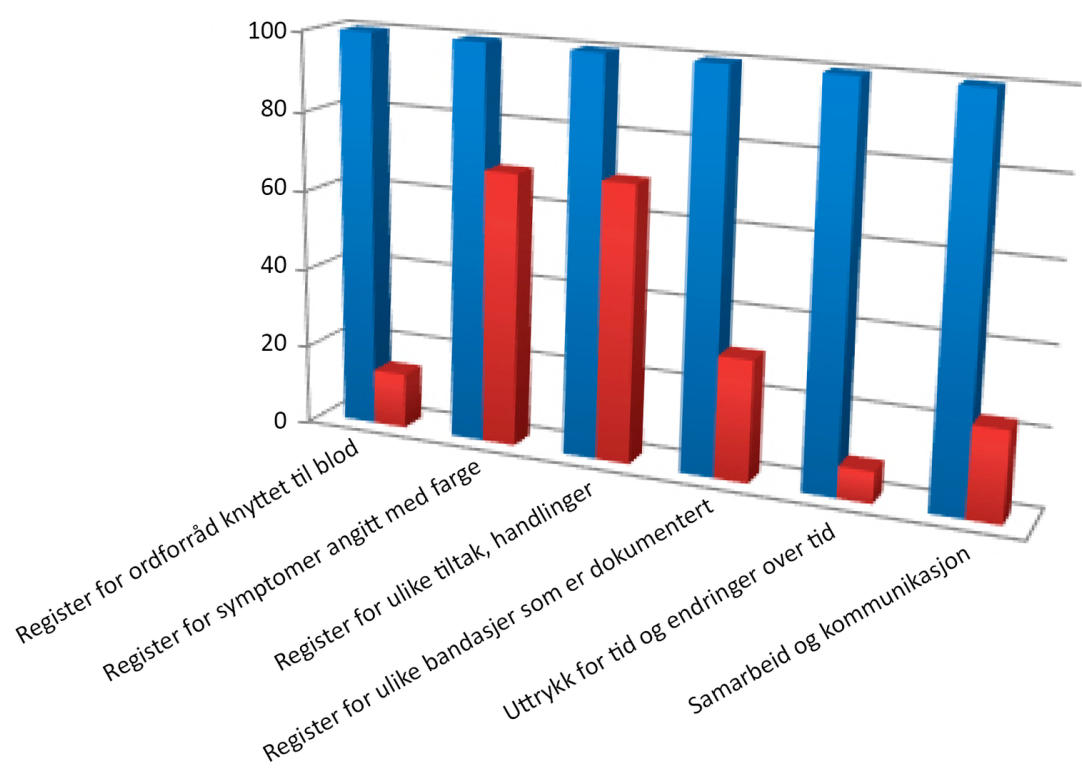




\section{Diskusjon}

Et hovedfunn er at de førstespråklige og de andrespråklige sykepleierne dokumenterer ulik mengde informasjon, og at den språklige presiseringen er forskjellig. I fire av de seks kategoriene dokumenterer andrespråklige mindre enn førstespråklige. I én kategori dokumenterer andrespråklige mer, og i én kategori er dokumentasjonsgraden relativt lik.

Detaljanalysen av hud, vev og sår viser at førstespråklige sykepleiere gjennomgående bruker et mer detaljert og nyansert språk i alle kategorier.

\section{三 «Et hovedfunn er at de førstespråklige og de andrespråklige sykepleierne dokumenterer ulik mengde informasjon.»}

Men funnene avdekker samtidig at de førstespråklige sykepleiernes dokumentasjon kan være mangelfull, slik andre studier også har vist (20). Kompetanse og kulturelle forhold som har betydning for hvordan andrespråklige sykepleiere ser på sin rolle og sitt ansvar, kan forklare noen av de forskjellene som er avdekket (2).

\section{Andrespråklige har smalere språkregister}

Andrespråklige sykepleiere bruker et smalere språkregister av substantiver, adjektiver og verb i sine beskrivelser av symptomer og handlinger. De trekker i liten grad inn annen informasjon fra før eller etter den vakten de rapporterer for.

Forskningen på andrespråk, det vil si læring, tilegnelse og anvendelse, er omfattende. Den er ikke entydig, men bekrefter at det kan innebære en flerårig prosess å utvikle et rikere språklig register når det gjelder å mestre god muntlig og skriftlig kommunikasjon (21). 
Henriksen (22) viser og begrunner slike forskjeller mellom førstespråkliges og andrespråkliges språktilegning og -læring. Flere kan fungere bra i dagligspråket etter relativt kort tid når de lærer seg et annet språk, men det kan ta flere år å tilegne seg et funksjonelt faglig språk. Disse erfaringene samsvarer med andrespråklige sykepleieres erfaringer i Norge også (2).

\section{Uttrykker tid forskjellig}

Vi avdekket forskjeller i å uttrykke tidsforhold, rekkefølge og tilstandsendringer for hud, vev og sår. Det kan være ulike grunner til forskjellene. De kan ha sammenheng med at de andrespråklige sykepleierne rapporterer mindre enn de førstespråklige og dermed også gir mindre uttrykk for relasjoner i tid.

En annen mulighet er at ulikhetene kan henge sammen med faglig kompetanse, men de kan også ha sammenheng med den språklige bakgrunnen til sykepleieren. I hvilken tid (tempus) et verb skrives, er avhengig av om det viser til noe som har skjedd, noe som skjer nå, beskriver en aktuell tilstand eller noe sykepleieren skal ta hensyn til fremover - for eksempel på neste vakt.

\section{三 «Vi avdekket forskjeller $\mathrm{i}$ å uttrykke tidsforhold, rekkefølge og tilstandsendringer for hud, vev og sår.»}

Informasjon knyttet til den aktuelle vakten krever stort sett notater med verb i presens, presens perfektum eller preteritum, som «spiser», «har spist» eller «spiste», og tidsadverb som «i morges» og «kl. 12» og liknende. Notater som henvender seg til den påtroppende sykepleieren, gjør det naturlig at sykepleieren bruker fremtid ved hjelp av verb som «skal», «kan», «må» og «bør» og tidsuttrykk som «i kveld» eller «neste uke». 
Notater som viser tilbake til foregående skift, krever at sykepleieren bruker fortidsformer som preteritum «spiste» eller preteritum perfektum for å vise til noe som skjedde før noe annet, som «hadde nettopp spist da han fikk smerter». Sistnevnte eksempel ble før kalt pluskvamperfektum. Selv nære fremmedspråk som engelsk, tysk, fransk og spansk uttrykker fortid ganske ulikt fra norsk.

Språk som vietnamesisk og kinesisk (mandarin) uttrykker ikke fortid ved hjelp av ulike endinger som på norsk (åpner - åpnet/åpna) eller endring av vokal (stå - sto), men ved tidsmarkører, på norsk for eksempel «i morges» og «på visitten» (23). Slike språkforskjeller kan forklare noen av funnene. De språklige utfordringene vi har avdekket, kan derfor variere etter hvilket førstespråk sykepleieren har, eller etter hvor sykepleierutdanningen er fullført.

Det kan utgjøre en forskjell for andrespråklige sykepleiere at norsk er et lite og fremmed språk som de sannsynligvis først har møtt i voksen alder, og som de har vært eksponert for i langt færre år og i mindre omfang enn for et verdensspråk som engelsk og spansk. Det kan bidra til større utfordringer i kommunikasjonen med pasienter og i samhandlingen med annet helsepersonell. Basert på funnene i studien vår har vi imidlertid ikke grunnlag for å si noe om slike utfordringer.

\section{Arbeidsgiver har ansvar for opplæring}

Vi kan ikke trekke slutninger om hvorvidt det er noen sammenheng mellom språkferdigheter og mulige mangler i den direkte behandlingen og oppfølgingen av pasienter. Formålet med studien har ikke vært av normativ karakter - det vil si å vurdere hvorvidt én gruppe av sykepleiere er bedre enn den andre. Vi har fokusert på å beskrive språklige likheter og forskjeller. 
Det kan være grunn til å reflektere over funnene i en utvidet kulturforståelse, der informasjonskultur er i forgrunnen (16). Da kan presisjon i beskrivelser og et mindre register over ord og uttrykk for å beskrive faglige vurderinger, handlinger og tiltak ha betydning.

Uansett hva årsaken er til språkutfordringene, har arbeidsgiveren plikt til å forvisse seg om at språkferdighetene til andrespråklige er på et nivå som sikrer at de kan dokumentere nøyaktig og presist, slik at tjenestene blir forsvarlige (24).

\section{Utvikler sykepleieterminologi}

Internasjonalt har det vært arbeidet med å utvikle terminologi til å bruke i journalføringen for sykepleiere, noe som kan forebygge noen av utfordringene $(25,26)$. Nasjonalt pågår det arbeid med å utvikle og innføre sykepleieterminologi, der Direktoratet for e-helse anbefaler å ta i bruk ICNP (International Classification for Nursing Practice). Da sykepleierne brukte fagspesifikk terminologi, ble innholdet mer fullstendig (27).

Sykepleiediagnoser kan imidlertid oppfattes som fremmende, språklige konstruksjoner (6). Derfor er det nødvendig med studier som adresserer hvorvidt bruken av fagterminologi bidrar til å støtte andrespråklige sykepleiere.

\section{Begrensninger ved studien}

Studien har flere begrensninger. Vi vet ikke om det er språklige ferdigheter alene eller også sykepleiefaglig kompetanse og kulturell bakgrunn som forårsaker ulikhetene (1). Det trengs mer kunnskap om den faktiske journalføringskvaliteten gjennom mer omfattende og robuste undersøkelser. Det vil også være ønskelig med en intervjuundersøkelse som gir mer dybdeinnsikt. 
Studien vår bygger på et begrenset antall vaktskifterapporter. Siden vi ikke fant tidligere studier om samme tema, brukte vi en metode som ga oss mulighet til å sammenlikne både omfanget og de språklige nyansene mellom gruppene. Det er en styrke at vi har analysert materialet på tvers av funksjonsområder fordi det gir en dypere forståelse av nyansene.

Ti av de andrespråklige hadde sykepleierutdanning fra Norge, mens de øvrige sju var utdannet i utlandet. Da vi sammenliknet disse gruppene, var det små forskjeller, og vi valgte derfor å samle dem i samme gruppe. Men funnene må vurderes i lys av at vi ikke har kunnet kontrollere for egenskaper ved informantene. Det er materialet for lite til.

Funnene må også vurderes i lys av at vi ikke har informasjon om hvor mange pasienter som er representert i rapportene. I tillegg var det etiske hensyn å ta. Siden vi har med få informanter i utvalget, kan vi ikke oppgi opphavslandet til de andrespråklige sykepleierne av anonymitetshensyn.

At de andrespråklige sykepleierne har et smalere ordforråd når de skriver, betyr ikke at vi kan trekke slutninger om kvaliteten på den direkte pasientomsorgen eller sykepleiernes kompetanse. Vi vet ikke om avdelingene har muntlig informasjonsoverføring mellom vaktene, og om det bidrar til kompensering av skriftlige mangler. Men muntlig rapport løser ikke nødvendigvis alle språkutfordringene (9).

Om deltakerne i denne studien har kjent seg presset til å delta, vet vi heller ikke. Hvis kulturelle forhold tilsier at de kjenner seg underlegne (2), kan det bety at gruppen vår ikke er representativ. Vi har heller ikke informasjon om innholdet i eller kvaliteten på rapportene til de sykepleierne som valgte ikke å delta, noe som kan påvirke resultatene. 


\section{Konklusjon}

Første- og andrespråklige sykepleiere journalfører nesten like mye tallrelatert informasjon, men i det språklige repertoaret og registeret er det klare forskjeller mellom gruppene. De førstespråklige sykepleierne bruker et større og mer nyansert repertoar enn andrespråklige sykepleiere. Studien gir ikke grunnlag for å trekke slutninger om at førstespråklige sykepleiere har feilfri journalføring.

Studien bør følges opp av større og bredere anlagte studier innen spesialist- og kommunehelsetjenesten og utdanningssektoren. Det er et lederansvar å sikre at ansatte får språklig og faglig oppfølging for å forebygge eventuell pasientrisiko. Studien kan bidra til å iverksette relevante tiltak som kan lette journalføringen for en sykepleiergruppe som er økende, og som Norge har bruk for.

Takk til kvalitetsansvarlig på sykehuset for tilrettelegging og bidrag i gjennomføringen av prosjektet og til Else Ryen for viktige innspill $i$ sluttfasen.

Lasse Morten Johannesen døde før artikkelen ble publisert. Artikkelen publiseres i samråd med pårørende.

\section{Referanser}

1. Jonsmoen K, Greek M. Studenter med norsk som andrespråk mangler nødvendige språkferdigheter. Sykepleien. 2018;106(72471)(e-72471). DOI: 10.4220/Sykepleiens.2018.72471

2. Dahl K, Dahlen KJ, Larsen K, Lohne V.

Conscientious and proud but challenged as a stranger: Immigrant nurses' perceptions and descriptions of the Norwegian healthcare system. Nordic Journal of Nursing Research. 2017;37(3):143-50. 
3. Ehrenberg A, Ehnfors M, Smedby B. Auditing nursing content in patient records. Scand J Caring Sci. 2001;15(2):133-41.

4. Gjevjon ER, Hellesø R. The quality of home care nurses' documentation in new electronic patient records. J Clin Nurs. 2009;19(1-2):100-8.

5. Saranto K, Kinnunen UM, Kivekas E, Lappalainen AM, Liljamo P, Rajalahti E, et al. Impacts of structuring nursing records: a systematic review. Scand J Caring Sci. 2014;28(4):629-47.

6. Nöst TH, Blekken LE, Andre B. Nurses' experiences with introduction of nursing diagnoses. Nordisk tidsskrift for helseforskning. 2015;11(1):89103.

7. Jefferies D, Johnson M, Nicholls D. Nursing documentation: how meaning is obscured by fragmentary language. Nurs Outlook. 2011;59(6):e6e12.

8. Jefferies D, Johnson M, Nicholls D, Langdon R, Lad S. Evaluating an intensive ward-based writing coach programme to improve nursing documentation: lessons learned. Int Nurs Rev. 2012;59(3):394-401.

9. Lauterbach A. ... da ist nichts, ausser dass das zweite Programm nicht geht Dienstübergaben in der Pflege. ff. 204-24 Reihe Pflegewissenschaft Norderstedt, Books on Demand GmbH; 2008. ISBN: 9-783-8370-43556.

10. Covell CL, Neiterman E, Bourgeault IL. Scoping review about the professional integration of internationally educated health professionals. Human resources for health. 2016;14(1):38. 
11. Lum L, Dowedoff P, Bradley P, Kerekes J, Valeo A. Challenges in oral communication for internationally educated nurses. J Transcult Nurs. 2015;26(1):83-91.

12. Philip S, Woodward-Kron R, Manias E, Noronha M. Overseas Qualified Nurses (OQNs) perspectives and experiences of intraprofessional and nurse-patient communication through a Community of Practice lens. Collegian. The Australian Journal of Nursing Practice, Scholarship \& Research. 2019;26(1):86-94. DOI: 10.1016/j.colegn.2018.04.002

13. Norsk Sykepleierforbund. Språkproblemer truer pasientsikkerheten. 2015. Tilgjengelig fra: https://www.nsf.no/visartikkel/2354192/539355/Spraakproblemer-truerpasientsikkerheten (nedlastet 05.01.2018).

14. Ot.prp. nr. 13 (1998-99). Om lov om helsepersonell mv. Oslo: Sosial- og helsedepartementet; 1998.

15. Statistisk sentralbyrå. Innvandrere og ikkebosatte 15-74 år med helse- og sosialfaglig utdanning sysselsatt i helse- og sosialtjenester, etter landbakgrunn, 2015. Tilgjengelig fra: https://www.ssb.no/270655/innvandrere-og-ikkebosatte-15-74-ar-med-helse-og-sosialfaglig-utdanningsysselsatt-i-helse-og-sosialtjenester-etterlandbakgrunn.per-4.kvartal.prosent-endring-siste-ar (nedlastet 07.05.2018).

16. Jylha V, Mikkonen S, Saranto K, Bates DW. The impact of information culture on patient safety outcomes. Development of a structural equation model. Methods Inf Med. 2017;56(Open):e30-e38.

17. Malterud K. Shared understanding of the qualitative research process. Guidelines for the medical researcher. Fam Pract. 1993;10(2):201-6. 
18. Helsedirektoratet. Meldeordningen for uønskede hendelser i spesialisthelsetjenesten. Oslo: Helsedirektoratet; 2016. Tilgjengelig fra: https://helsedirektoratet.no/Lists/Publikasjoner/Attach ments/1365/\%C3\%85rsrapport\%202016\%20meldeord ningen\%20for\%20u\%C3\%B8nskede\%20hendelser\%2 0i\%20spesialisthelsetjenesten.pdf (nedlastet 20.01.2018).

19. Knudsen CW, Tonseth KA. Pressure ulcers prophylaxis and treatment. Tidsskr Nor Laegeforen. 2011;131(5):464-7.

20. Wang N, Yu P, Hailey D. The quality of paperbased versus electronic nursing care plan in Australian aged care homes: a documentation audit study. Int J Med Inform. 2015;84(8):561-9.

21. Chenu F, Jisa H. Reviewing some similarities and differences in L1 and L2 lexical development. Aile Acquisition et interaction en langue étrangère. 2009;1:17-38. Tilgjengelig fra: https://journals.openedition.org/aile/4506 (nedlastet 15.04.2018).

22. Henriksen B. Research on L2 learners' collocational competence and development - a progress report. I: Bardel C, Lindqvist C, Lauffer B, red. L2 vocabulary acqusition, knowledge and use new perspectives on assessment and corpus analysis 2 : Eurosla Monographs series. Italia: University of Modena and Reggio Emilia; 2013. s. 11-29.

23. Chan L. Tense-aspect processing in second language learners. Pittsburgh, Pennsylvania, Faculty of the Dietrich School of Arts and Sciences, University of Pittsburgh; 2012. 
24. Statens helsetilsyn. Arbeidsgiver har ansvar for å ansette helsepersonell med språkferdigheter [internett]. Oslo: Statens helsetilsyn; 2015 [oppdatert 23.01.2015; sitert 20.01.2018]. Tilgjengelig fra: https://www.helsetilsynet.no/presse/nyhetsarkiv/2015/a rbeidsgiver-har-ansvar-for-a-ansette-helsepersonellmed-sprakferdigheter/.

25. Hardiker N. Harmonising ICNP and SNOMED CT: a model for effective collaboration. Stud Health Technol Inform. 2016;225:744-5.

26. Hardiker NR, red. Developing standardized terminologies in nursing informatics. Sudbury, MA: Jones and Bartlett Publisher; 2009.

27. Thoroddsen A, Ehnfors M, Ehrenberg A. Content and completeness of care plans after implementation of standardized nursing terminologies and computerized records. Computers, Informatics, Nursing: CIN. 2011;29(10):599-607. 